УДК 339.542 .22

Дунська А.P.

канд. економ. наук, доцент

Локота А.Г.

Національній технічний університет Украӥні «КПI»

\title{
ПРОБЛЕМИ ТА ПЕРСПЕКТИВИ РОЗВИТКУ МІЖНАРОДНОЇ ТОРГІВЛІ ЛІЦЕНЗІЯМИ В УКРАЇНІ
}

\author{
ПРОБЛЕМЫ И ПЕРСПЕКТИВЫ РАЗВИТИЯ МЕЖДУНАРОДНОЙ \\ ТОРГОВЛИ ЛИЦЕНЗИЯМИ В УКРАИНЕ
}

\section{PROBLEMS AND PROSPECTS OF INTERNATIONAL TRADE LICENSES IN UKRAINE}

Проведено аналіз міжнародної торгівлі ліџензіями на світовому рівні, визначені країни та галузі, які займають значну частку лічензійного ринку. Розглянуто обсяг експорту послуг $і$ імпорту в світі за географічною та галузевою структурою за 2005-2013 рік та географічну структуру поданих заявок на отримання патентів в 2014 рочі. Також виділені 5 сфер, які займають лідируючу позицію за обсягом поданих заявок на патенти.

В роботі проаналізовані основні закономірності розвитку світового ринку ліцензій та визначена роль міжнародної лічензійної торгівлі в світовому господарстві. Наведений аналіз стану міжнародної торгівлі ліщензіями в Україні: обсяг та основні джерела фінансування інновачійної діяльності в Украйні за 2010-2012рр.

В статті надано аналіз динаміки структури експорту-імпорту послуг України за видом послуги - «Роялті та інші послуги» та структура зовнішньої торгівлі послугами за 9 місяців 2014 року в сфері ліщензійних договорів. Розглянуті найвагоміші партнери України за видом послуги «Роялті та лічензійні угоди». В статі виявлені основні проблеми ліщензійної торгівлі та розглянуті подальші перспективи ринку ліџензій в Украӥні.

Ключові слова: ліцензія, міжнародна торгівля ліцензіями, патент, передача технологій, інновація.

Проведен анализ международной торговли лищензиями на мировом уровне, определены страны и области, которые занимают весомую долю лицензионного рынка. Рассмотрена динамика объема экспорта услуг и импорта в мире по географической и отраслевой структуре за 2005-2013 год и географическая структура поданных заявок на получение патентов в 2014 году. Также выделены 5 сфер, которые занимают лидирующую позичию по объему поданных заявок на патенты.

В работе проанализированы основные закономерности развития мирового рынка лицензий и определена роль международной лицензионной торговли в мировом хозяйстве. Приведенный анализ международной торговли лицензиями в Украине: объем и основные источники финансирования инновационной деятельности в Украине за 2010-2012г2. В статье подан анализ динамики структуры экспорта-импорта услуг Украины по виду услуги - «Роялти и другие услуги» и структура внешней торговли услугами за 9 месяцев 2014 года в сфере лицензионных договоров. Рассмотрены наиболее значимые партнеры Украины по виду услуги «Роялти и лицензионные соглашения». В статье выявлены 
основные проблемы лицензионной торговли и рассмотрены дальнейшие перспективы рынка лицензий в Украине.

Ключевые слова: лицензия, международная торговля лицензиями, патент, передача технологий, инновация.

It was analysed international trade licenses on a global level, determined country and sector, which occupy a significant share of the market license. We consider the volume of exports and imports of services worldwide geographical and sectorial structure for the 2005-2013 year and the geographic structure of applications for patent in 2014. Also, highlighted 5 areas, that occupy a leading position in terms of applications for patents.

This work analysed the basic laws of the world market licenses and the role of international trade license in the world economy. The above analysis of international trade licenses in Ukraine: the volume and main sources of financing of innovative activity in Ukraine for 2010-2012. The work analyses the dynamics of the structure of exports and imports of services by type of service Ukraine - "Royalties and other services" and the structure of foreign trade in services for 9 months of 2014 in the field of licensing agreements. Considered the most significant partners of Ukraine, by type of service "Royalty and license agreements." The article identified the main problems licensed trade and discussed further perspectives of the licenses in Ukraine.

Key words: license, international trade licenses, patents, technology transfer, innovation.

Вступ. На сучасному етапі одним 3 ключових завдань економічного розвитку України є визначення нового виміру іiі інтеграції у світовуекономіку. Одним із варіантів вирішення цього завдання є розширення участі країни у світовій торгівлі ліцензіями, що дозволить Україні отримати переваги від високого інтелектуального потенціалу і забезпечить просування української економіки в високоприбуткову сферу.

Перетворення інновацій в головну силу економічного розвитку сучасної світової економіки обумовлює активізацію процесів міжнародного науковотехнічного обміну. Світова практика свідчить, що основною комерційною формою міжнародної передачі технологій є ліцензійна торгівля.

Теоретичну та методологічну основу дослідження сформували праці провідних вітчизняних i зарубіжних вчених в сфері світової торгівлі ліцензіями, інтелектуальної власності та світової економіки: АлдошинаВ. М.,Богуславського М.M., Бромберга Г.В., Донця I.M., Градобітовой Л.Д., Котлера Ф., Коултера М., Мансфільд Е., Радеби ЈI.Х., Робінса С. та ін.

Первинними джерелами дослідження $\epsilon$ міжнародні угоди в сфері світової торгівлі, захисту та комерціалізації інтелектуальної власності, міжнародного інвестування, статистичні матеріали та публікації міжнародних економічних організацій (СОТ, ЮНКТАД, WIPO), статистичні збірники (УКРСТАТ).

Постановка завдання. Метою дослідження $є$ розглянути економічну сутність міжнародних ліцензійних операцій, проаналізувати міжнародну торгівлю ліцензіями визначити ї роль в світовому господарстві, 
проаналізувати стан, проблеми та перспективи ринку ліцензій в Україні. Визначити роль та місце України у міжнародній торгівлі ліцензіями.

Методологія дослідження являє собою поєднання базових компонентів наукового пізнання, таких як діалектична логіка, методи системного аналізу, економіко-статистичні методи.

Результати дослідження.Міжнародна торгівля ліцензіями являється вигідною як для ліцензіара, так і для ліцензіата. Відзначається, що кожен долар, витрачений на покупку іноземної ліцензії, за своїм ефектом еквівалентний (без урахування фактору часу) в США приблизно 6,2 дол., у Великобританії - 3,1, у Франції - 5,4, інвестованих в НДДКР [1].

Лідером в експорті ліцензій виступають Сполучені Штати Америки, які $\epsilon$ єдиною великою країною світу, що має позитивне сальдо патентноліцензійного обміну. Визнаним лідером 3 імпорту ліцензій в останні десятиріччя є Японія. Обсяги закупівлі науково-технічних досягнень цією країною $є$ не тільки найбільшими, а й такими, що перевищують обсяги імпорту технічних досягнень таких індустріально розвинутих країн, як США, Великобританія, Італія, Франція.

Найбільша частина торгівлі ліцензіями припадає на наступні галузі: електротехнічна й електронна промисловість - $19 \%$, загальне машинобудування - 18\%; хімічна промисловість - 17,4\%, транспортне машинобудування - 10,2\% всього обсягу комерційних операцій [2].

Останнімчасом достатньо швидко розвивається галузь програмного забезпечення на ліцензійному ринку. Одним 3 найяскравіших прикладів $\epsilon$ компанія Microsoftта реалізація ліцензій компанії на використання Microsoft Windows 8, обсяг яких перевищив показник 200 млн. одиниць через 15 місяців після запуску.

В загальному обсязі експорту та імпорту послуг за останні спостерігаємо позитивну динаміку по усім напрямкам продажу послуг (табл. 1).

Таблиця 1

Обсяги експорту послуг і імпорту в світі, 2005-2013 pp. (млн дол США)

\begin{tabular}{|c|c|c|c|c|c|c|c|}
\hline Рік & Область & 2005 & 2008 & 2010 & 2011 & 2012 & 2013 \\
\hline Світ & Всього & $\mathbf{2 5 7 3 2 2 0}$ & $\mathbf{3 9 1 6 2 0 0}$ & $\mathbf{3 8 9 6 2 6 0}$ & $\mathbf{4 3 7 2 8 9 0}$ & $\mathbf{4 4 7 3 8 1 0}$ & $\mathbf{4 7 2 0 1 8 0}$ \\
\cline { 2 - 8 } & Транспорт & 569280 & 890670 & 807470 & 880140 & 888450 & 905940 \\
\cline { 2 - 8 } & Подорожі & 703010 & 963200 & 951500 & 1064510 & 1104230 & 1183630 \\
\cline { 2 - 8 } & Інші сервіси & 1298600 & 2059180 & 2129940 & 2419750 & 2474660 & 2625940 \\
\cline { 2 - 8 } & Послуги зв'язку & 59400 & 97700 & 97160 & 106340 & 111160 & 121150 \\
\cline { 2 - 7 } & Будівельні послуги & 56050 & 112150 & 99410 & 106580 & 107010 & 105140 \\
\cline { 2 - 8 } & Страхування & 49400 & 83490 & 96720 & 105300 & 104160 & 102570 \\
\cline { 2 - 8 } & Фінансові послуги & 180550 & 298620 & 282110 & 316870 & 308470 & 334930 \\
\hline
\end{tabular}




\begin{tabular}{|c|c|c|c|c|c|c|c|}
\hline & $\begin{array}{c}\text { Комп'ютерні та } \\
\text { інформаційні } \\
\text { послуги }\end{array}$ & 103820 & 195190 & 213810 & 249530 & 261370 & 286810 \\
\cline { 2 - 7 } & $\begin{array}{c}\text { Роялті та ліцензійні } \\
\text { угоди }\end{array}$ & 159690 & 228740 & 255470 & 290270 & 293470 & 309860 \\
\cline { 2 - 8 } & Інші ділові послуги & 609370 & 944850 & 983670 & 1128780 & 1172740 & 1247230 \\
\cline { 2 - 8 } & $\begin{array}{c}\text { Послуги приватним } \\
\text { особам та в сфері } \\
\text { культури та } \\
\text { відпочинку }\end{array}$ & 23280 & 29300 & 33010 & 38620 & 39470 & 42450 \\
\cline { 2 - 8 } СС & Державні послуги & 57040 & 69140 & 68580 & 77480 & 76810 & 75800 \\
\cline { 2 - 8 } & $\begin{array}{c}\text { Роялті та ліцензійні } \\
\text { угоди }\end{array}$ & 48970 & 75920 & 90890 & 103600 & 98850 & 108040 \\
\hline
\end{tabular}

Складено автором на основі [3]

Розглядаючи складову «Роялті та ліцензійні угоди» спостерігаємо, що у 2013 році було здійснено операцій, в цій сфері, на суму 309860 млн. дол. США (третя частина, яких були здійсненні на території Європейського Союзу), що на 603330 млн. дол.США більше ніж в 2012 році, що у відсотковому значенні складає 6\%. Це свідчить про позитивну динаміку в збільшенні операцій та угод на ліцензійному ринку.

Географія поширення інновацій на світовому ринку технологій $\epsilon$ вкрай нерівномірною і має чітку залежність від науково-технічних потенціалів країн. 9/10 світового обсягу патентів та ліцензій, а також витрат на науководослідні та проектно-експериментальні розробки, надходжень і платежів за трансфер технологій припадає на десятку ринково розвинутих країн.

За 9 останніх місяців 2014 року організація WIPO склала рейтинги країн за кількістюподаних заявок на патенти, що свідчить про інноваційну активність країн та вагому роль на ринку торгівлі ліцензіями та «ноу-хау».

За підрахунками організації в 2014 році було подано 205300 заявок на патенти, що на 5,1\% більше ніж в 2013 році. Географічна структура заявок представлена в табл. 2.

Таблиця 2

Географічна структура поданих заявок на патенти в 2014 році

\begin{tabular}{|c|c|c|}
\hline Ранг & Країна & Кількість заявок \\
\hline 1 & США & 57239 \\
\hline 2 & Японія & 43918 \\
\hline 3 & Китай & 21516 \\
\hline 4 & Німеччина & 17927 \\
\hline 5 & Корея & 12386 \\
\hline 6 & Франція & 7899 \\
\hline 7 & Велика Британія & 4865 \\
\hline 8 & Швейцарія & 4367 \\
\hline
\end{tabular}




\begin{tabular}{|c|c|c|}
\hline 9 & Нідерланди & 4198 \\
\hline 10 & Швеція & 3960 \\
\hline
\end{tabular}

Складено автором на основі [4]

Також в дослідженні представлені Топ-5 сфер за кількістю заявок в цій галузі. Найбільшу частку зайняла галузь електричне машинобудування, приладобування та енергетика - 14897 заявок, що на 10,9 \% більше ніж в попередньому періоді. На другому місці комп'ютерні технології 14684 заявок, на третьому - цифровий зв'язок, четверте місце - медичні технології та п'яте - прилади вимірювання.

Помітна зростаюча тенденція в кількості заявок на патенти, в обсязі експорту та імпорту ліцензійних угод та в загальній кількості операцій на ліцензійному ринку свідчить про інноваційну спрямованість світових лідерів.

В порівнянні 3 розвинутими країнами фактичне місце України на світовому ринку науково-технічних досягнень незначне. Це зумовлено низьким ступенем участі як в експорті високих технологій, в першу чергу, через низьку результативність діяльності національної інноваційної сфери, так і в імпорті. Україна виробляє значно меншу частку наукомісткої продукції на світовому ринку, ніж її частка в світовому науково-технічному потенціалі.

Однією із головних причин такого становища $є$ недостатні обсяги фінансування та недосконала його структура, що вимагає оптимізації. Джерела фінансування інноваційної діяльності в Україні за 2010-2012 pp. представлена у табл. 3.

Таблиця 3

Джерела фінансування інноваційної діяльності в Україні 2010-2012 рр.

\begin{tabular}{|c|c|c|c|c|c|}
\hline & \multirow{2}{*}{$\begin{array}{c}\text { Загальна сума } \\
\text { витрат }\end{array}$} & \multicolumn{4}{|c|}{ У тому числі за рахунок коштів } \\
\hline & & власних & $\begin{array}{c}\text { державного } \\
\text { бюджету }\end{array}$ & $\begin{array}{l}\text { іноземних } \\
\text { інвесторів }\end{array}$ & $\begin{array}{c}\text { iнші } \\
\text { джерела }\end{array}$ \\
\hline & \multicolumn{5}{|c|}{ млн. грн. } \\
\hline 2010 & 8045,5 & 4775,2 & 87,0 & 2411,4 & 771,9 \\
\hline 2011 & 14333,9 & 7585,6 & 149,2 & 56,9 & 6542,2 \\
\hline 2012 & 11480,6 & 7335,9 & 224,3 & 994,8 & 2925,6 \\
\hline
\end{tabular}

Складено автором на основі [5]

Результати табл. 3. вказують на зниження загальної суми витрат у 2012 р. відносно 2011 р. $з$ 14333,9 млн. грн., до 11480,6 млн. грн. Також дані таблиці свідчать, що найбільшим джерелом фінансування інноваційної діяльності в Україні є власні джерела.

Єдина конкурентна перевага країни в цьому аспекті, це традиційно сильні ІТ-кадри, тобто дуже високий рівень підготовки програмістів, оскільки Україна є одним зі світових центрів офшорного програмування [6]. 
Наступним кроком в характеристиці розвитку ринку ліцензій в Україні $\epsilon$ аналіз динаміки структури експорту-імпорту послуг ( табл.4).

Таблиця 4 Динаміка структури експорту-імпорту послуг (за видом послуги - «Роялті та інші послуги»), 2005-2013pр., тис.дол. США

\begin{tabular}{|c|c|c|c|c|c|c|c|c|}
\hline \multirow{2}{*}{$\begin{array}{c}\text { Найменування } \\
\text { послуги } \\
\text { згідно з КЗЕП }\end{array}$} & \multicolumn{4}{|c|}{ Експорт } & \multicolumn{4}{|c|}{ Імпорт } \\
\hline & 2005 & 2011 & 2012 & 2013 & 2005 & 2011 & 2012 & 2013 \\
\hline Усього & 6134742 & 13792217 & 13599128 & 14836264 & 2934996 & 6235194 & 6736071 & 7608976 \\
\hline $\begin{array}{c}\text { Роялті та інші } \\
\text { послуги, } \\
\text { пов’язані } з \\
\text { використ. } \\
\text { інтелект. } \\
\text { власності }\end{array}$ & 9751,3 & 46067,7 & 56416,2 & 97668,0 & 209609,6 & 411838,9 & 419815,5 & 854214 \\
\hline
\end{tabular}

Складено автором на основі [5]

Як зазначено в таблиці 4, експорт роялті та ліцензійних угод в 2013 році має позитивну динаміку, наприклад, в 2013 році показник більший від попереднього на 41251 тис. дол. США, що у відсотковому значенні дорівнює $58 \%$. Імпорт ліцензійних послуг збільшився на $49 \%$ в 2013 році в порівнянні 3 2012 роком. Такий високий показник росту експорту та імпорту свідчить про зростання ролі України на ринку ліцензій та «ноу-хау».

Структура зовнішньої торгівлі послугами в 2014 році надана в таблиці 5. В таблиці ми спостерігаємо від'ємне сальдо в торгівлі послугами та низьку частку торгівлі роялті у відношенні до загального обсягу торгівлі послугами. Вона складає 0,5 \% експорту (для порівняння в США вона складає 4,8\%) та 7,6\% загального імпорту послуг. Це свідчить про необхідність розвитку цього напряму експорту та імпорту послуг.

Таблиця 5

Структура зовнішньої торгівлі послугами за 9 місяців 2014 року

\begin{tabular}{|c|c|c|c|c|c|c|c|}
\hline \multirow[b]{2}{*}{$\begin{array}{c}\text { Найменування } \\
\text { послуги згідно } \\
\text { з КЗЕП }\end{array}$} & \multicolumn{3}{|c|}{ Експорт } & \multicolumn{3}{|c|}{ Імпорт } & \multirow[b]{2}{*}{ Сальдо } \\
\hline & $\begin{array}{c}\text { тис.дол } \\
\text { США }\end{array}$ & $\begin{array}{l}\text { у \% до } \\
9 \text { міс. } \\
2013 p .\end{array}$ & $\begin{array}{l}\text { у \% до } \\
\text { обсягу, } \\
\text { розділу } \\
\text { всього } \\
\end{array}$ & $\begin{array}{c}\text { тис.дол. } \\
\text { США }\end{array}$ & $\begin{array}{l}\text { у \% до } \\
9 \text { міс. } \\
2013 p .\end{array}$ & $\begin{array}{l}\text { у \% до } \\
\text { обсягу, } \\
\text { розділу } \\
\text { всього }\end{array}$ & \\
\hline Усього & 8685909 & 83,5 & 100,0 & 4262539 & 79,3 & 100,0 & 4423369 \\
\hline $\begin{array}{c}\text { Роялті та інші } \\
\text { послуги, } \\
\text { пов’язані } 3 \\
\text { використанням } \\
\text { інтелектуальної } \\
\text { власності }\end{array}$ & 41252,9 & 78,5 & 0,5 & 326015,9 & 70,9 & 7,6 & $-284763,0$ \\
\hline
\end{tabular}

Складено автором на основі [5] 
Зовнішня торгівля послугами України 3 іншими країнами надана в таблиці 6., в таблицю були занесені найвагоміші партнери України за видом послуги «Роялті та ліцензійні угоди». Найбільший обсяг експорту роялті Україна має 3 Росією (14228 тис.дол. США),, що становить 0,5 \% до загального обсягу країни. А імпорт ліцензій зі Швейцарії (105349,5 тис. дол. США), що складає 37,2 \% від загального обсягу країни. Спостерігається негативне сальдо майже 3 усіма країнами партнерами. Виключеннями є: Казахстан, Білорусь та Молдова.

Пріоритетом України залишається розвиток експорту власних ліцензій та «ноу-хау» 3 метою отримання прибутку та імпорту технологій з розвинених країн для оновлення та збагачення технологічного та інноваційного потенціалу країни.

Більшість операцій з ліцензіями проходять всередині корпорацій, і не завжди оприлюднюються, проте ліцензійний потенціал України значний.

Але існує ціла низка причин, що знижують ефективність процесу розвитку ліцензійної торгівлі в Україні:

1) Однією 3 них, найбільш важливою, $є$ відсутність механізму регулювання зовнішньої торгівлі українськими ліцензіями, що призводить до безоплатної втрати національного інтелектуального ресурсу.

Таблиця 6

Зовнішня торгівля послугами України з країнами світу

(за видом послуги - «Роялті та інші послуги») за 9 місяців 2014 року

\begin{tabular}{|c|c|c|c|c|c|}
\hline & \multicolumn{2}{|c|}{ Експорт } & \multicolumn{2}{|c|}{ Імпорт } & Сальдо +/- \\
\cline { 2 - 6 } & $\begin{array}{c}\text { Обсяг } \\
\text { звітного } \\
\text { періоду, } \\
\text { тис.дол. } \\
\text { США }\end{array}$ & $\begin{array}{c}\text { У \% до } \\
\text { відовідного } \\
\text { періоду } \\
\text { ринулого } \\
\text { року }\end{array}$ & $\begin{array}{c}\text { Обсяг } \\
\text { звітного } \\
\text { періоду, } \\
\text { тис.дол. } \\
\text { США }\end{array}$ & $\begin{array}{c}\text { У \% до } \\
\text { відповідного } \\
\text { періоду } \\
\text { минулого } \\
\text { року }\end{array}$ & \\
\hline В С ь О Г О & 41252,9 & 78,5 & 326015,9 & 70,9 & $-284763,0$ \\
\hline Росія & 14228,1 & 79,0 & 28454,5 & 83,1 & $-14226,4$ \\
\hline Велика Британія & 6512,6 & 164,3 & 47316,1 & 113,8 & $-40803,5$ \\
\hline Швейцарія & 5231,7 & 95,4 & 105349,5 & 146,1 & $-100117,8$ \\
\hline Кіпр & 3725,8 & 98,5 & 38008,4 & 20,5 & $-34282,6$ \\
\hline США & 2002,4 & 95,2 & 23748,2 & 88,5 & $-21745,8$ \\
\hline Казахстан & 1299,1 & 91,6 & 32,7 & 129,4 & 1266,4 \\
\hline Німмечина & 905,4 & 90,2 & 21647,6 & 79,0 & $-20742,2$ \\
\hline Білорусь & 758,7 & 86,5 & 373,9 & 133,8 & 384,9 \\
\hline Чехія & 548,6 & 51,0 & 699,1 & 56,7 & $-150,5$ \\
\hline Нідерланди & 318,0 & 75,4 & 9815,5 & 125,9 & $-9497,5$ \\
\hline Молдова & 304,8 & 81,3 & 11,3 & 90,1 & 293,5 \\
\hline Австрія & 209,2 & 99,8 & 5732,2 & 80,8 & $-5523,0$ \\
\hline
\end{tabular}




\begin{tabular}{|c|c|c|c|c|c|}
\hline Японія & 81,3 & 57,1 & 480,2 & 5,8 & $-398,9$ \\
\hline Китай & 36,3 & 21,9 & 74,1 & 762,8 & $-37,9$ \\
\hline
\end{tabular}

Складено автором на основі [5]

2) Недостатній рівень кваліфікащії фахівиів у цій новій для більшості підприємств діяльності.

3) Практично всі підприємства намагаються передати за кордон новітні знання в чистому вигляді, але не враховують вкладу виробничих знань, секретів та інжинірингових послуг. Така стратегія українських підприємств різко відрізняється від загальносвітових тенденцій, де однією 3 найбільш характерних рис сучасного ліцензійного обміну є загострення конкурентної боротьби і значне ускладнення доступу до новітніх технологій і обмеженню їх комерційного використання.

4) $90 \%$ промислової продукції, що випускається українськими підприємствами, в тому числі за новітніми технологіями, не відповідає світовому рівню i, отже, є неконкурентоспроможною.

5)У більшості підприємств відсутня єдина політика в галузі охорони промислової власності та експорту товарів і технологій, що різко знижує можливість розширення продажу ліцензій.

6) Більшість запропонованих українськими підприємствами технологій мають обмежене промислове впровадження. Звідси випливає й наступна проблема низької ціни експортованих українських ліцензій, яка ускладнюється не використанням методик розрахунку ціни у підприємств.

7) Імпорт ліцензій та обладнання здійснюється без врахування такого важливого чинника міжнародної торгівлі, як права, якими володіють підприємства-ліцензіати.

8) Важливою проблемою імпорту ліцензій є його економічна значимість. На жаль, не всі підприємства, купуючи ліцензії, віддають собі звіт в тому, що ліцензійні платежі становлять тільки частину імпорту. Нерідко вартість технологічного обладнання та комплектуючих, необхідних для впровадження технології, у два-три рази перевищує вартість самої ліцензії. А затягування термінів впровадження знижує новизну і конкурентоспроможність ліцензійної продукції.

9) Також значною проблемою вітчизняного ринку ліцензій і ноу-хау $\epsilon$ «відтік мозку» закордон, нездатність держави сформувати певні умови для створення об'єктів для ліцензування.

Вирішення перелічених проблем має стати значним кроком вперед, i, враховуючи потенціал України, кроком до створення конкурентоспроможних позицій на світовому ринку ліцензування.

Перспективи: 1) Оскільки винахідницька та патентна активність $є$ основною передумовою науково-технологічного обміну, то, важливою для 
України є інтеграція у міжнародний ринок патентів та винаходів, що надасть можливість не тільки користуватися винаходами, патенти яких перебувають у власності суб'єктів інших країн, а й розвивати власну винахідницьку й патентну діяльність [1, с. 16].

2) Пріоритетним заходом у завоюванні іноземних ринків $\epsilon$ ефективний захист та збереження права власності на винаходи, корисні моделі, промислові зразки за вітчизняними винахідниками, які потенційно змогли б виступали ліцензіарами, укладаючи угоди із іноземними партнерами.

3) Відкриття світових ринків дає можливість науковцям вигідно користуватися своїм інтелектуальним доробком, проте вони переважно не мають досвіду підприємницької діяльності і не завжди розуміють правила гри на міжнародному ринку інтелектуальної власності.

4) Важливим заходом у цьому напрямі вбачається підвищення рівня інформаційної освіченості винахідників з методиками оцінки вартості прав на об’єкти інтелектуальної власності, обізнаності їх 3 діяльністю інститутів патентних повірених та відповідних державних установ.

5) 3 огляду на важливість ролі держави у створенні сприятливих умов для розвитку високотехнологічної сфери в Україні видається доцільним надання підтримки винахідникам на усіх етапах патентування.

6) Крім того, на державному рівні доцільно здійснювати контроль за виділенням квот з Державного бюджету, передбачених Законом України «Про державне регулювання діяльності у сфері трансферу технологій» для забезпечення фінансування закордонного патентування винаходів.

Висновки. Наукова новизна проведеного дослідження полягає у систематизації факторів що заважають розширеній участі України у патентноліцензійній торгівлі. До таких факторів слід віднести: необгрунтованість державної політики у даній сфері, недостатній рівень міжнародного науковотехнічного співробітництва країни, відсутність мотивації винахідництва, що загалом не дає можливості заявити про свої досягнення на міжнародному технологічному ринку.

Не створивши сприятливих умов для розвитку високотехнологічного виробництва, не визначивши його як пріоритетний напрям розвитку економіки, Україна втрачатиме не лише доходи, а й основний рушій інноваційного розвитку країни. Крім того, країна буде позбавлена права, будь-яким, чином впливати на політику, що реалізується на міжнародному ринку продукції високих технологій, а цим правом успішно користуються такі країни, як США, Великобританія, Німеччина, Франція та Японія.

Отже, розвиток міжнародної ліцензійної торгівлі $\epsilon$ каталізатором науково-технічної й інноваційної діяльності. Купівля-продаж ліцензій створює бажання і можливості для впровадження науково-технічних розробок 
у виробництво що, у свою чергу, закладає базу для їхнього швидкого відмирання, інтенсифікації інноваційного процесу в умовах глобалізації.

\section{Література:}

1.WorldInvestmentReport 2012: Investingin a Low-Carbon Economy // $20^{\text {th }}$ AnniversaryEdition. PrintedinSwitzerland. - $184 \mathrm{c}$.

2. Science\&Technology. WorldBank. [Електронний pecypc]. - Режим доступу: http://data.worldbank.org/topic/science-and-technology

3.International trade in services [Електроннийресурс] //UNCTADstat Table of International trade 2013. Режим доступу:http://stats.unctad.org/

4. WorldIntellectualPropertyOrganization[Електронний ресурс]. - Режим доступу: http://www.wipo.int/portal/en/index.html

5. Державний комітет статистики [Електронний ресурс]. - Режим доступу: http://www.ukrstat.gov.ua/.

6. Омельяненко В.А. Міжнародний трансфер технологій в контексті побудови високотехнологічної економіки [Електронний ресурс]. - Режим доступу:http://fei.idgu.edu.ua/conference/dokl/d111.pdf. 